\title{
PEMODELAN DAN SIMULASI MAXIMUM POWER POINT TRACKING MENGGUNAKAN ADAPTIVE NEURO FUZZY INFERENCE SYSTEM PADA APLIKASI FOTOVOLTAIK DENGAN KONVERTER CUK
}

\author{
Abil Huda \\ Program Studi Teknik Elektro, Universitas Borneo Tarakan, Kaltara, Indonesia
}

e-mail: abildengineer.com

\begin{abstract}
Fossil fuels have a finite number such as coal and petroleum. It encourages the development of renewable energy as an alternative energy source powerhouse. PV maximum power is controlled using MPPT method for improving the performance of $P V$. Research conducted on the application method MPPT PV system using Cuk converter. This was done by various methods MPPT. This study uses Adaptive Neuro Fuzzy Inference System (ANFIS) as MPPT to track the maximum power point. Analysis and simulation of the proposed system has been carried out. PV can generate maximum power with irradiation and temperature variations both in static conditions. ANFIS can work well as an MPPT control on the $P V$ system against irradiation and temperature changes in static conditions. Accuracy of $P V$ power on the condition of irradiation and temperature variation are above $90 \%$.
\end{abstract}

Keywords-MPPT, ANFIS, Konverter Cuk, PV

Intisari-Penelitian ini menggunakan metode Adaptive Neuro Fuzzy Inference System (ANFIS) dalam pemodelan Maximum Power Point Tracking (MPPT) untuk mengontrol konverter Cuk sehingga fotovoltaik (PV) menghasilkan daya maksimum. Sistem ini menggunakan Fotovoltaik $200 \mathrm{~W}$ dan konverter Cuk dengan desain teganganterhubung beban. Dari hasil penelitian, PV dapat menghasilkan daya maksimum dengan variasi iradiasi dan temperatur pada kondisi statis. ANFIS dapat bekerja dengan baik dalam menjejak titik daya maksimum atau sebagai kontrol MPPT pada sistem PV terhadap perubahan iradiasi dan temperatur dalam kondisi statis. Akurasi daya PV terhadap daya maksimum pada kondisi variasi iradiasi dan temperatur berada di atas $90 \%$.

Kata Kunci-MPPT, ANFIS, Konverter Cuk, PV

\section{Pendahuluan}

Kebutuhan energi listrik semakin meningkat. Hal ini disebabkan oleh pertumbuhan jumlah masyarakat di suatu daerah yang mengakibatkan bertambahnya jumlah infrastruktur seperti bangunan tempat tinggal, kantorkantor, sekolah, rumah sakit dan bangunan sosial lainnya. Berkembangnya jumlah infrastruktur menyebabkan konsumen listrik semakin meningkat. Sehingga diperlukan penambahan energi listrik.

Saat ini bahan bakar fosil berupa minyak bumi dan batu-bara masih menjadi sumber energi yang paling banyak digunakan dalam proses pembangkitan tenaga listrik. Bahan bakar fosil tersebut tidak dapat diperbarui dan jumlahnya semakin menipis seiring dengan berjalannya waktu. Karena kebutuhan energi listrik semakin hari semakin meningkat, sumber energi alternatif terutama sumber energi terbarukan menjadi semakin dibutuhkan [1].

Salah satu sumber energi terbarukan adalah Photovoltaic (PV) yang memanfaatkan energi cahaya matahari. Sumber energi ini memiliki kelebihan yaitu bersih dan tersedia di alam dalam jumlah yang melimpah [2].

Permasalahan dalam penggunaan PV saat ini adalah efisiensinya yang masih rendah dengan biaya yang tinggi. Kebutuhan penggunaan PV yang semakin meningkat mendorong berbagai penelitian mengenai peningkatan efisiensi pada sistem PV. Terdapat tiga faktor yang mempengaruhi efisiensi sistem PV. Pertama adalah material PV. Kedua adalah efisiensi konverter dan efisiensi algoritma Maximum Power Point Tracking (MPPT) [3].

PV dapat memberikan daya output sesuai dengan kapasitas. Kapasitas daya output maksimal PV dapat dihasilkan dengan penggunaan metode Maximum Power Point Tracking (MPPT).

Cuk converter adalah konverter DC-DC pengembangan dari konverter Buckboost. Konverter ini dapat menaikkan dan menurunkan tegangan. Komponen rangkaian konverter Cuk terdiri dari sebuah switch, sebuah dioda, dua induktor dan dua kapasitor. Dibandingkan dengan konverter buckboost, Cuk converter mempunyai arus input dan output yang kontinu. Sehingga ripple yang dihasilkan juga kecil [4].

Adaptive Neuro Fuzzy Inference System (ANFIS) merupakan metode yang menggunakan jaring syaraf tiruan (Neural Network) untuk mengimplementasikan Fuzzy Inference System (FIS) atau sistem inferensi fuzzy. Keunggulan sistem inferensi fuzzy adalah dapat menerjemahkan pengetahuan dari pakar dalam bentuk aturan-aturan, namun biasanya dibutuhkan waktu yang lama untuk menetapkan fungsi keanggotaannya. Oleh sebab itu dibutuhkan teknik pembelajaran dari jaringan syaraf tiruan untuk mengotomatisasi proses tersebut sehingga dapat mengurangi waktu pencarian, hal tersebut menyebabkan metode ANFIS sangat baik untuk diterapkan pada MPPT [5].

Penelitian ini menggunakan metode ANFIS sebagai MPPT yang mengontrol Cuk converter untuk aplikasi sistem PV. 


\section{LANDASAN TEORI}

\section{A. PV}

PV mempunyai kemampuan untuk mengubah energi cahaya menjadi energi listrik. Energi cahaya membangkitkan tegangan PV. PV yang terhubung beban akan menyebabkan arus PV mengalir.

PV mempunyai karakteristik tegangan (V) dan arus (I) yang nilainya berdasarkan iradiasi dan temperatur. Kurva I-V dapat menunjukkan titik daya maksimum. Kurva I-V didapatkan berdasarkan 2 kondisi yaitu short circuit dan open circuit. Ketika kondisi short circuit, arus maksimum atau arus short circuit (ISC) dihasilkan, sedangkan pada kondisi open circuit tidak ada arus yang dapat mengalir sehingga tegangannya maksimum, disebut tegangan open circuit $\left(\mathrm{V}_{\mathrm{OC}}\right.$ ). Titik pada kurva I-V yang menghasilkan arus dan tegangan maksimum disebut titik daya maksimum (MPP). Pemodelan rangkaian ekivalen PV adalah sebuah sumber arus yang terpasang paralel dengan sebuah diode seperti ditunjukkan pada gambar 1. Besar arus output dari suatu PV berbanding lurus dengan besar iradiasi cahaya matahari yang diterima oleh PV.

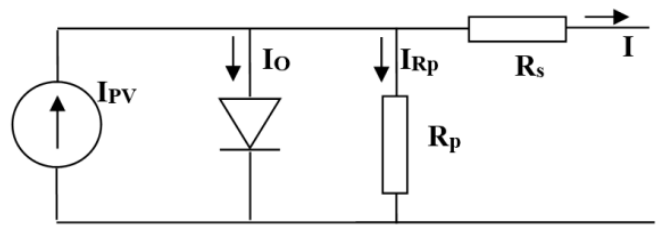

Gambar 1. Pemodelan Sistem

Karakteristik PV didapatkan menggunakan persamaan (1). [5]

$I=I_{P V}-I_{O}\left[e^{\left(\frac{V+1 R s}{N k T / 4)}\right)}-1\right]-\left(\frac{V+I R s}{R_{P}}\right)$

Keterangan:

$I \quad=$ arus output $\mathrm{PV}(\mathrm{A})$.

$I_{P V}=$ arus yang terbangkit pada $\mathrm{PV}(\mathrm{A})$.

$I_{O} \quad=$ arus saturasi dioda.(A)

$N_{s} \quad=$ jumlah cell terhubung seri.

$k=\operatorname{konstanta}$ Boltzman $(\mathrm{j} / \mathrm{K})$.

$T=$ temperatur $(\mathrm{K})$

$q=$ muatan elektron $=1.6 \times 10^{-19}($ Coloumb $)$

$R_{S} \quad=$ tahanan seri (Ohm).

$R_{P}=$ tahanan paralel $(\mathrm{Ohm})$.

$V \quad=$ tegangan output $\mathrm{PV}(\mathrm{V})$.

Karakteristik I-V PV diobservasi bahwa nilai Rs mendominasi tegangan operasi $\mathrm{PV}$ sedangkan nilai $\mathrm{Rp}$ mendominasi arus operasi PV. Ketika nilai tahanan paralel $\mathrm{Rp}$ tinggi, maka arus yang melaluitahanan paralel $\mathrm{Rp}$ dapat di abaikan.

Iradiasi matahari berbanding lurus dengan arus yang dihasilkan PV dan juga dipengaruhi oleh temperatur diberikan pada persamaan (2).Tarek, B., Said, D., \& Benbouzid, M.E.H. (2013)

$$
I_{p v}=\left[I_{p v, n}+K_{I} \Delta_{T}\right] \frac{G}{G_{n}}
$$

Keterangan:

$I_{p v}=$ arus pada kondisi nominal $\left(25^{\circ} \mathrm{C}\right.$ dan 1000 $\left.\mathrm{W} / \mathrm{m}^{2}\right)$

$$
\Delta T=T-T_{n}
$$

$T=$ temperatur aktual $(\mathrm{K})$.

$T_{n}=$ temperatur nominal $(\mathrm{K})$

$K_{I}=$ koefisien arus.

$G=$ iradiasi aktual $\left(\mathrm{W} / \mathrm{m}^{2}\right)$.

$G_{n}=$ iradiasi nominal $\left(\mathrm{W} / \mathrm{m}^{2}\right)$.

Koefisien arus $\mathrm{K}_{\mathrm{I}}$ dan tegangan $\mathrm{Kv}$ dimasukkan sebagaimana yang ditunjukkan dalam persamaan (3) untuk mendapatkan arus saturasi I o yang dipengaruhi langsung oleh temperatur.Tarek, B., Said, D., \& Benbouzid, M.E.H. (2013)

$I_{o}=\frac{I_{s c, n}+K_{I} \Delta_{T}}{e^{\left(\frac{\left(\frac{V_{o c, n}+K_{V} \Delta_{T}}{a V_{t}}\right)}{V_{t}}\right)}-1}$

Keterangan:

$I_{o}=\operatorname{arus}$ saturasi (A)

$I_{s c, n}=$ arus hubung singkat $(\mathrm{A})$

$V_{o c, n}=$ tegangan hubung terbuka $(\mathrm{V})$

$K_{I}=$ koefisien arus.

$K_{V}=$ koefisien tegangan.

$\Delta T=T-T_{n}$

$T=$ temperatur aktual $(\mathrm{K})$

$T_{n}=$ temperatur nominal $(\mathrm{K})$.

$V_{T}=N_{S} k T / q$

\section{B. Konverter Cuk}

Konverter Cuk adalah converter DC-DC pengembangan dari converter BuckBoost. Konverter ini dapat menghasilkan tegangan keluaran yang lebih besar maupun lebih kecil dari tegangan masukkan dengan polaritas terbalik serta mempunyai arus masukkan dan keluaran yang kontinu. Mayssa, F. \& Sbita, L. (2012).

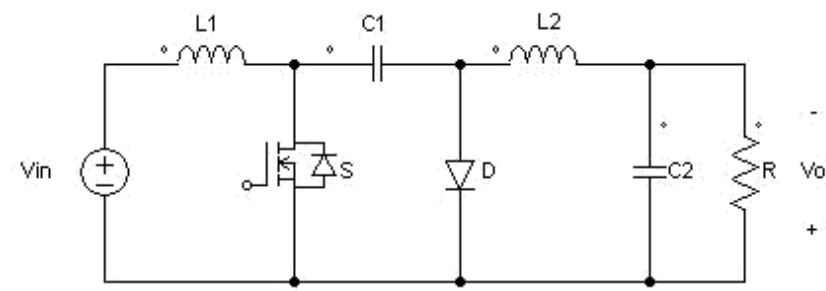

Gambar 2. Rangkaian Konverter Cuk

Konverter cuk digunakan untuk menaikkan tegangan PV dan menyalurkan daya maksimum. Hubungan antara tegangan masukkan dan tegangan keluaran diberikan pada 
persamaan (4). Mayssa, F. \& Sbita, L. (2012).

$V_{o}=-\frac{D}{1-D} V_{i n}$

$\mathrm{D}$ adalah duty cycle yang bernilai antara 0 sampai 1 . Duty cycle yang bernilai 0 - 0,49 akan menghasilkan tegangan keluaran yang lebih kecil dari tegangan masukkan. Duty cycle yang bernilai 0,5 - 1 akan menghasilkan tegangan yang lebih besar dari tegangan masukkan.

\section{ANFIS}

Metode ANFIS memiliki struktur yang terdiri dari 5 layer yang masing-masing layernya mempunyai fungsi yang berbeda-beda seperti yang ditunjukkan pada Gambar 3. berikut:

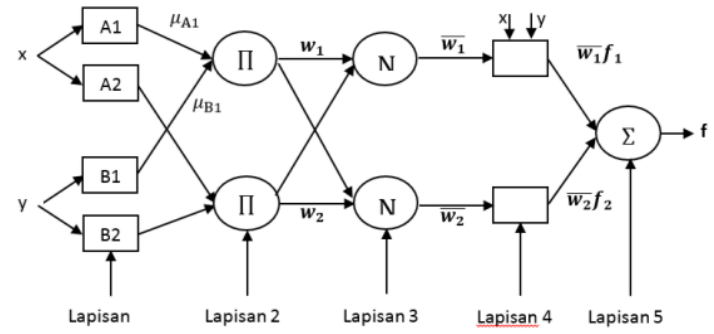

Gambar 3. Struktur ANFIS

Lapisan 1: Setiap simpul pada lapisan ini adalah simpul adaptif (parameter yang dapat berubah) dengan fungsi simpul:

$$
\begin{array}{ll}
O_{1, i}=\mu_{A i-}(x), & i=1,2 \text { atau } . \\
O_{1, i}=\mu_{B i-2}(y), & i=3,4 \ldots \ldots \ldots . . .
\end{array}
$$

Lapisan 2: Setiap simpul pada lapisan ini adalah nonadaptif (parameter tetap). Fungsi simpul ini adalah mengalikan setiap sinyal masukan yang datang. Fungsi simpul:

$$
O_{2, i}=w_{i}=\mu_{A i}(x) \mu_{B i}(y), \quad i=1,2
$$

Lapisan 3: Setiap simpul pada lapisan ini adalah simpul nonadaptif yang menampilkan fungsi derajat pengaktifan ternormalisasi (normalized firing strength) yaitu rasio output simpul ke-i pada lapisan sebelumnya terhadap seluruh output lapisan sebelumnya, dengan bentuk fungsi simpul:

$$
O_{3, i}=\overline{w_{l}}=\frac{w_{i}}{w_{1}+w_{2}}, \quad i=1,2
$$

Lapisan 4: Setiap simpul pada lapisan ini adalah simpul adaptif dengan fungsi simpul:

$$
O_{4, i}=\bar{w}_{l} f_{i}=\overline{w_{l}}\left(p_{i} x+q_{i} y+r_{i}\right) \quad i=1,2
$$

Lapisan 5: Pada lapisan ini hanya ada satu simpul tetap yang fungsinya untuk menjumlahkan semua masukan. Fungsi simpul:

$$
O_{5,1}=\sum \bar{w}_{l} f_{i}=\frac{\sum w_{i} f_{i}}{\sum w i}
$$

\section{Metode Penelitian}

Sistem terdiri dari PV, konverter cuk dan kontrol MPPT.

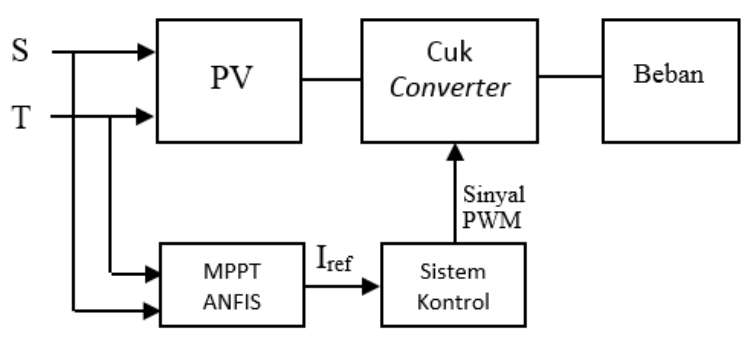

Gambar 4. Pemodelan Sistem

Tabel I

Parameter PV KC200GT

\begin{tabular}{|c|c|r|}
\hline No. & Parameter & \multicolumn{1}{|c|}{ Nilai } \\
\hline 1. & Impp & $7,7 \mathrm{~A}$ \\
\hline 2. & Vmpp & $25,98 \mathrm{~V}$ \\
\hline 3. & Pmax & $200 \mathrm{~W}$ \\
\hline 4. & Isc & $8,21 \mathrm{~A}$ \\
\hline 5. & Voc & $32,9 \mathrm{~V}$ \\
\hline 6. & Rp & $415,405 \Omega$ \\
\hline 7. & Rs & $0,00684 \Omega$ \\
\hline
\end{tabular}

Tabel II

Parameter Konverter Cuk

\begin{tabular}{|c|c|r|}
\hline No. & Parameter & \multicolumn{1}{|c|}{ Nilai } \\
\hline 1. & Vi & $25,98 \mathrm{~V}$ \\
\hline 2. & Vo & $-220 \mathrm{~V}$ \\
\hline 3. & L1 & $0,003 \mathrm{H}$ \\
\hline 4. & L2 & $0,026 \mathrm{H}$ \\
\hline 5. & C1 & $3,695 \mu \mathrm{F}$ \\
\hline 6. & C2 & $0,026 \mu \mathrm{F}$ \\
\hline
\end{tabular}

\section{Kontrol MPPT ANFIS}

MPPT adalah metode menjejak titik daya maksimum disetiap kondisi iradiasi matahari dan temperatur. Keluaran ANFIS adalah arus referensi Impp (maximum power point) yang merupakan arus pada titik daya maksimum. Impp akan dieksekusi oleh cuk converter untuk memastikan PV membangkitkan arus yang sama dengan arus referensi yang dihasilkan oleh ANFIS. Jika PV membangkitkan arus di Impp, maka PV akan menghasilkan daya maksimum.

Masukkan ANFIS adalah iradiasi matahari dan temperatur. Keluaran adalah arus referensi berupa Impp.Stuktur ANFIS terdiri dari dua masukkan dengan 7 fungsi keanggotaan segitiga, 49 rule dan 1 keluaran.

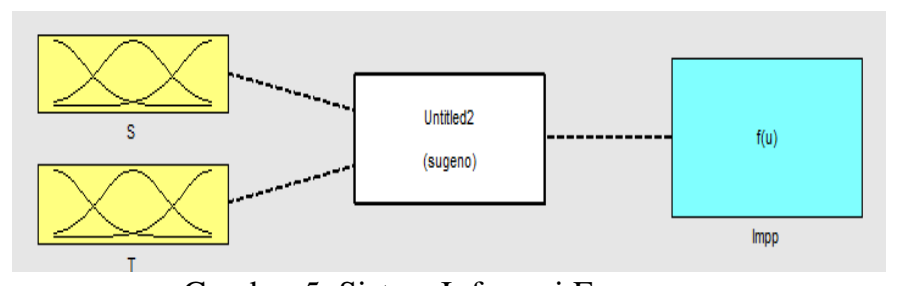

Gambar 5. Sistem Inferensi Fuzzy 


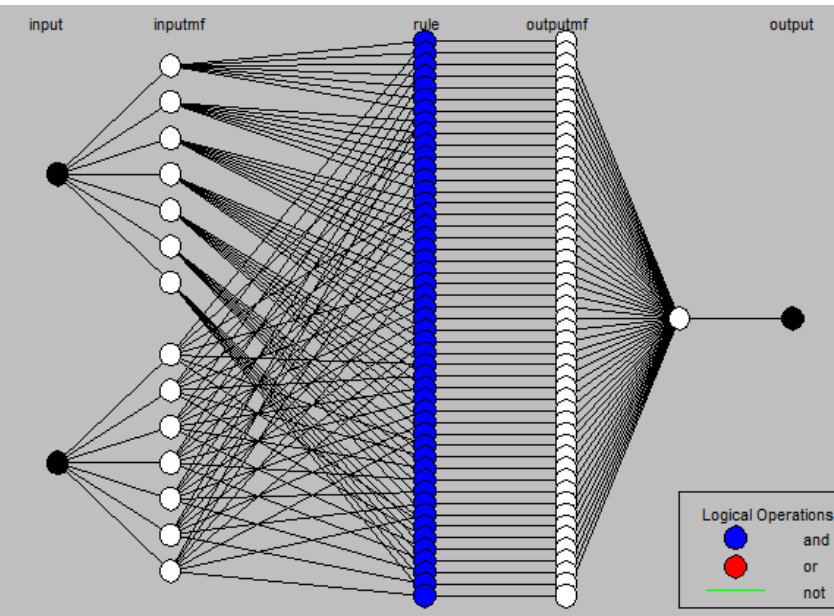

Gambar 6.. Struktur ANFIS

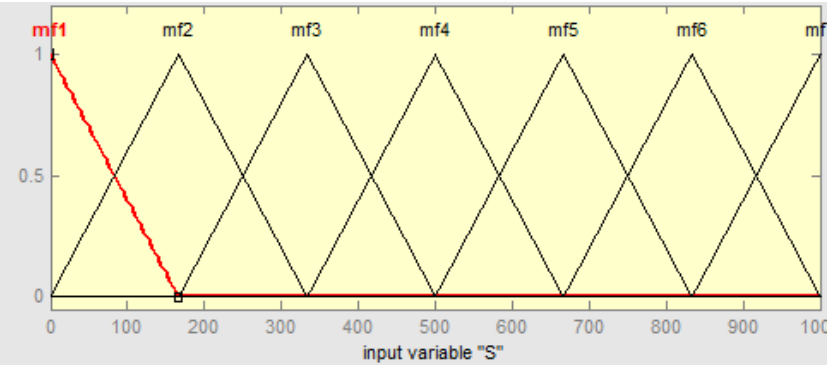

Gambar 7. Fungsi Keanggotaan Iradiasi Matahari

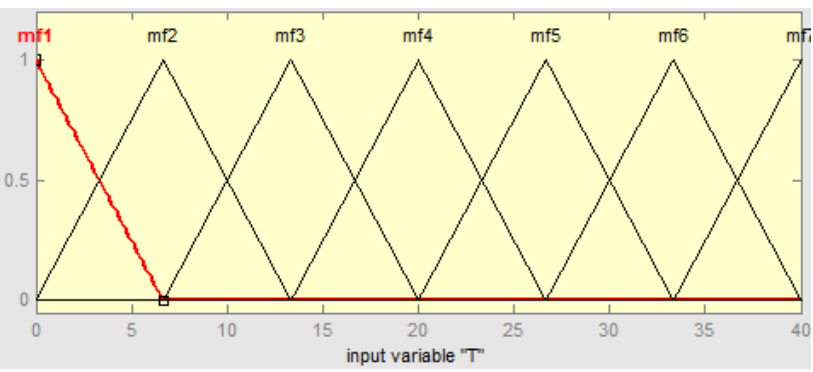

Gambar 8. Fungsi Keanggotaan Temperatur

\section{IV.HASIl Dan PEMbahasan}

Pemodelan sistem seperti gambar 4. telah dicoba. Input PV dicoba dalam kondisi statis dengan variasi iradiasi dan temperatur. Kondisi variasi iradiasi dimulai dari $1000 \mathrm{~W} / \mathrm{m}^{2}, 800 \mathrm{~W} / \mathrm{m}^{2}, 600 \mathrm{~W} / \mathrm{m}^{2}$, sampai dengan $400 \mathrm{~W} / \mathrm{m}^{2}$. Kondisi variasi Temperatur dimulai dari $10^{\circ} \mathrm{C}$, $25^{\circ} \mathrm{C}$, sampai dengan $40^{\circ} \mathrm{C}$.

\section{Kondisi Statis variasi Iradiasi temperatur $25^{\circ} \mathrm{C}$}

Gambar 9. menunjukkan bahwa daya yang dihasilkan oleh PV (Ppv) ketika iradiasi $1000 \mathrm{~W} / \mathrm{m}^{2}$ sebesar 200 Watt. Daya maksimum ketika iradiasi $1000 \mathrm{~W} / \mathrm{m}^{2}$ sebesar 200 Watt. Hal ini berarti kontrol MPPT ANFIS mampu menjejak titik daya maksimum.

Gambar 10. menunjukkan bahwa daya yang dihasilkan oleh PV (Ppv) ketika iradiasi $800 \mathrm{~W} / \mathrm{m}^{2}$ sebesar $161 \mathrm{Watt}$. Daya maksimum ketika iradiasi $800 \mathrm{~W} / \mathrm{m}^{2}$ sebesar 159,7 Watt. Hal ini berarti kontrol MPPT ANFIS mampu menjejak titik daya maksimum.

Gambar 11. menunjukkan bahwa daya yang dihasilkan oleh PV (Ppv) ketika iradiasi $600 \mathrm{~W} / \mathrm{m}^{2}$ sebesar $121 \mathrm{Watt}$ Daya maksimum ketika iradiasi $600 \mathrm{~W} / \mathrm{m}^{2}$ sebesar 121
Watt. Hal ini berarti kontrol MPPT ANFIS mampu menjejak titik daya maksimum.

Gambar 12. menunjukkan bahwa daya yang dihasilkan oleh PV (Ppv) ketika iradiasi $400 \mathrm{~W} / \mathrm{m}^{2}$ sebesar 80 Watt. Daya maksimum ketika iradiasi $400 \mathrm{~W} / \mathrm{m}^{2}$ sebesar 79 Watt. Hal ini berarti kontrol MPPT ANFIS mampu menjejak titik daya maksimum.

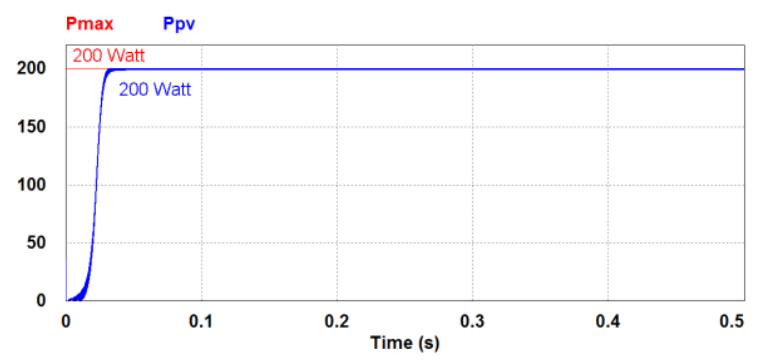

Gambar 9. Daya PV iradiasi $1000 \mathrm{~W} / \mathrm{m}^{2}$

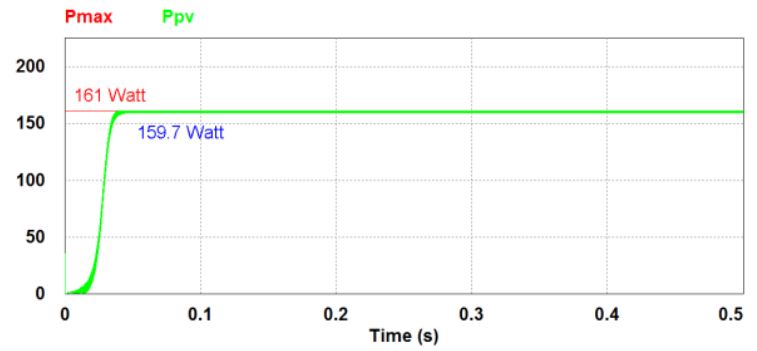

Gambar 10. Daya PV iradiasi $800 \mathrm{~W} / \mathrm{m}^{2}$

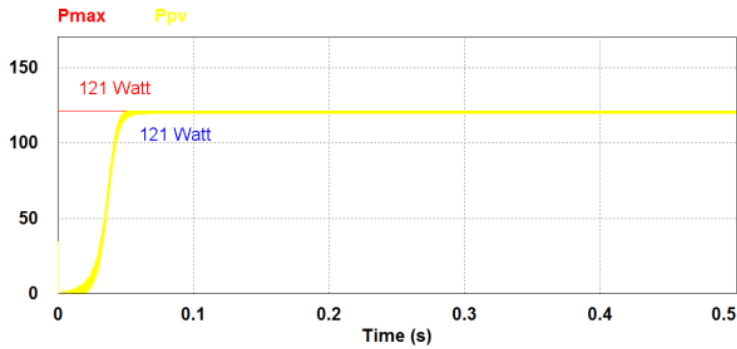

Gambar 11. Daya PV iradiasi $600 \mathrm{~W} / \mathrm{m}^{2}$

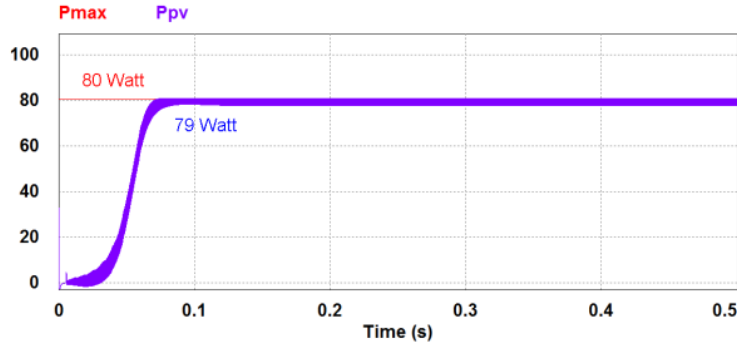

Gambar 12. Daya PV iradiasi $400 \mathrm{~W} / \mathrm{m}^{2}$

Gambar 9. sampai 12. menunjukkan bahwa daya yang dihasilkan oleh PV (Ppv) mendekati daya maksimum (Pmax). Hal ini berarti kontrol MPPT ANFIS memiliki respon yang baik dalam menjejak titik daya maksimum diberbagai kondisi iradiasi yang berbeda-beda.

Kondisi Statis Iradiasi $1000 \mathrm{~W} / \mathrm{m}^{2}$ variasi temperatur 


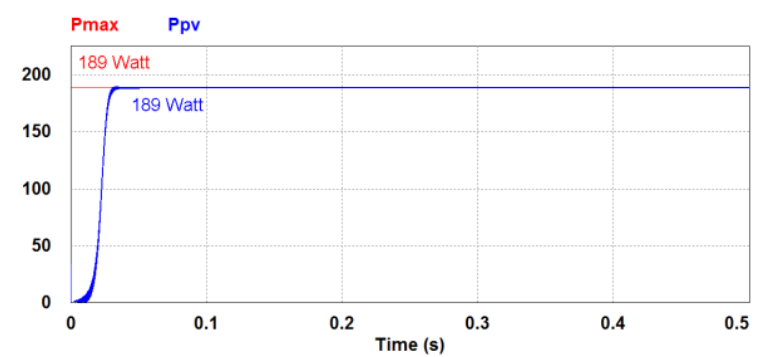

Gambar 13. Daya PV Temperatur $40^{\circ} \mathrm{C}$

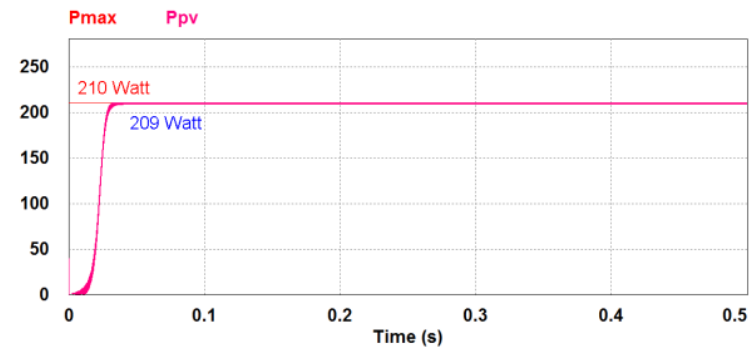

Gambar 14. Daya PV Temperatur $10^{\circ} \mathrm{C}$

Gambar 13 menunjukkan bahwa daya yang dihasilkan oleh PV (Ppv) ketika temperatur $40^{\circ} \mathrm{C}$ sebesar 189 Watt. Daya maksimum ketika iradiasi $40^{\circ} \mathrm{C}$ sebesar 189 Watt. Hal ini berarti kontrol MPPT ANFIS mampu menjejak titik daya maksimum.

Gambar 14 menunjukkan bahwa daya yang dihasilkan oleh PV (Ppv) ketika temperatur $10^{\circ} \mathrm{C}$ sebesar 210 Watt. Daya maksimum ketika iradiasi $10^{\circ} \mathrm{C}$ sebesar 209 Watt. Hal ini berarti kontrol MPPT ANFIS mampu menjejak titik daya maksimum.

Gambar 13 sampai 14 menunjukkan bahwa daya yang dihasilkan oleh PV (Ppv) mendekati daya maksimum (Pmax). Hal ini berarti kontrol MPPT ANFIS memiliki respon yang baik dalam menjejak titik daya maksimum diberbagai kondisi temperatur yang berbeda-beda.

\section{KESIMPULAN}

Berdasarkan hasil analisis dan simulasi, maka diambil beberapa kesimpulan diantaranya PV menghasilkan daya maksimum dengan variasi iradiasi. PV menghasilkan daya maksimum dengan variasi temperatur. ANFIS mampu bekerja sebagai MPPT. Kontrol MPPT ANFIS memiliki respon yang baik dalam menjejak titik daya maksimum diberbagai kondisi iradiasi dan temperatur.

\section{REFERENSI}

[1] Sankarganesh, R. \& Thangvel, S. 2012, Maximum Power Point Tracking in PV System using Intelligence based $P \& O$ Technique and Hybrid Cuk Converter, 2012-International Conference on Emerging Trends in Science, Engineering and Technology. pp. 429-436.

[2] Soedibyo, Priananda, C. W. \& Haikal, M. A., Maximum Power Point Tracking Using Root Finding Modified Bisection Algorithm, International Conference on Information Technology, Computer and Electrical Engineering (ICITACEE), pp. 394-399.

[3] Devi, M. L. \& Chilambarasan, M. 2013, Design and Simulation of Incremental Conductance MPPT Using Self
Lift Cuk Converter, 2013 International Conference on Renewable Energy and Sustainable Energy [ICRESE' 13]

[4] Sahu, T. P. \& Dixit, T.V. 2012, Modelling and Analysis of Peturb \& Observe and Incremental Conductance MPPT Algorithm for PV Array Using Cuk Converter, 2012 IEEE Student's Conference on Electrical, Electronics and Computer Science. pp. 1-6.

[5] Tarek, B., Said, D., \& Benbouzid, M.E.H. 2013, Maximum Power Point Tracker Control for Photovoltaic System Using Adaptive Neuro-Fuzzy "ANFIS", 2013 Eighth International Conference and Exhibition on Ecological Vehicles and Renewable Energies (EVER), IEEE. 